\title{
Short-term effects of territoriality of a tropical damselfish and experimental exclusion of large fishes on invertebrates in algal turfs
}

\author{
Dirk C. Zeller* \\ Department of Marine Biology, James Cook University of North Queensland, Townsville, Queensland, Australia
}

\begin{abstract}
This study investigated the effects of territorial behaviour of the pomacentrid Stegastes apicalis and exclusion of fishes on the abundance and composition of small mobile invertebrates associated with algal turfs on a fringing coral reef. The experiment tested for the effects of territoriality, caging, and large and small spatial scales of variability, utilizing standardized experimental substrata (plates of Porites). After 3 mo densities of invertebrates and algal biomass were greater on experimental plates inside territories than outside territories. Caging resulted in an increase in densities of mobile invertebrates, but was accompanied by a change in algal composition and a reduction (inside territories) or no change (outside territories) in algal biomass. The discrepancy between densities and algal abundance in caged treatments could have been caused by increased grazing intensity by the herbivorous components of the invertebrate fauna. This micrograzing (sensu Vadas 1986) is thought to account for the observed shift in species composition of algae.
\end{abstract}

\section{INTRODUCTION}

Multispecific assemblages of filamentous algae, generally termed algal turfs (Carpenter 1986), are thought to be the major source of primary production in coral reef systems (Hatcher 1983). Grazing is considered to have a major influence on the species composition, abundance and standing crop of algae on coral reefs (Hay 1985, Carpenter 1986, Lewis 1986). Considerable information exists on herbivorous grazers and their interaction with algae (reviews by Ogden \& Lobel 1978, Hixon 1985). The most important grazers on coral reefs of the Great Barrier Reef are considered to be fishes (Hatcher 1983), and a significant increase in biomass of algae following exclusion of grazing fishes has frequently been reported (e.g. Day 1977, Lassuy 1980). Thus, much evidence suggests that grazing plays an important role in controlling the standing crop of algal turfs on coral reefs (Hatcher \& Larkum 1983).

In contrast, little is known about small, mobile invertebrates that live associated with such algal turfs. Sev-

\footnotetext{
- Present address: Schwimmbadstr. 3, D-7834 Herbolzheim, Federal Republic of Germany
}

eral lines of evidence suggest that these small inverte brates may be of substantial trophodynamic importance in coral reefs. First, many are likely to graze directly on the algal turfs, yet their contribution to total grazing pressure on coral reefs relative to the larger herbivorous grazers is almost totally unknown (Carpenter 1986). Second, these small, mobile invertebrates are likely to be a major source of food for fishes. This is supported strongly by the observation that communities of coral reef fishes are often dominated by fishes which feed on benthic invertebrates (e.g. Sale 1980, Harmelin-Vivien 1981).

It is possible that the abundance of these invertebrates is affected significantly by a complex relationship between the grazing activities of large herbivores, the standing crop of algal turfs, and the predatory feeding of fishes. Such a relationship has been demonstrated in other sublittoral systems of plant/herbivore interactions (e.g. Kennelly 1983).

Clearly, any factor which influences standing crop of algal turf may affect the abundance of small, mobile invertebrates. One of the most obvious influences on standing crop of algal turfs on coral reefs is the territorial behaviour of certain herbivorous fishes (Lassuy 1980). One such herbivore which is very common on 
inshore reefs of the Great Barrier Reef is the pomacentrid Stegastes (= Eupomacentrus) apicalis (De Vis) (Allen 1975), which defends its territory against other herbivorous fishes as well as against its conspecifics. By reducing the intensity of grazing by non-territorial fishes (such as scarids and acanthurids) on the algae, territorial fishes increase the standing crop of algal turfs inside territories (Brawley \& Adey 1977, Lassuy 1980). Despite some recent reports (Lobel 1980, Carpenter 1986), little is known about the effects on the mobile invertebrate fauna of this increased standing crop of algal turfs inside territories.

The present study examined the effect of territoriality by Stegastes apicalis, and the effect of exclusion of large grazers and predators on the densities of small, mobile invertebrates associated with algal turfs.

\section{METHODS}

Study sites. The study location was on a windward fringing reef on Orpheus Island $\left(18^{\circ} 135^{\prime} \mathrm{S}, 146^{\circ} 29^{\prime} \mathrm{E}\right)$, a coastal island of the Palm group in the central Great Barrier Reef region. The crests of 2 coral patchreefs approximately $300 \mathrm{~m}$ apart on the upper reef slope were selected as study areas. The patchreefs were considered to be subjected to similar conditions of wave action and waterflow. The crest of each patchreef had 5 to 8 territories of adult-sized damselfish Stegastes apicalis ( 110 to $140 \mathrm{~mm}$ total length), 3 of which I selected as territorial sites. In each area 3 non-territorial sites, each approximately the same size as individual territories, were chosen between 5 and $15 \mathrm{~m}$ from the territorial sites. They were defined as not being part of an obviously defended territory of any pomacentrid, as determined during a 20 min observation period. The non-territorial status of these sites was confirmed during each subsequent visit. The depth of all sites was between 1.5 and $2.5 \mathrm{~m}$ below chart datum (port of Lucinda).

Experimental design. The experiment was designed as a 4 -factor, mixed-model analysis of variance, comprising the following factors: (1) Area', i.e large spatial scale represented by the 2 areas described above; (2) 'Territoriality', i.e. non-territorial and territorial treatments; (3) 'Sites', smaller spatial scale, i.e. individual territories or non-territorial habitats as described above; (4) 'Caging', caged and uncaged treatments, enabling the effect of exclusion of large grazers to be assessed. Factors 1, 2 and 4 were orthogonal and fixed in the analyses, while Factor 3 , being nested within Factors 1 and 2, was a random factor. Throughout the following, the term 'sites nested within area and territoriality' will be referred to simply as 'sites'

Coral plates (made of dead Porites, approximately
$8 \times 8 \times 2.5 \mathrm{~cm}$ j were used as standardized substrata Plates were attached directly to the natural substratum using stainless steel screws. Cages of size $12.5 \times 12.5 \times$ $6.5 \mathrm{~cm}$, made of galvanised welded mesh (mesh size $12.5 \mathrm{~mm}$ square, wire diameter $1.3 \mathrm{~mm}$ ) were used to exclude grazers and predators larger than $12.5 \mathrm{~mm}$ minimum dimension. Each plate was caged separately. Replication consisted of 3 plates per treatment combination (i.e. 3 caged and 3 uncaged plates per site), resulting in a total of 72 plates.

Data collection. The experiment was done over a 3 mo period (February to May 1986) during which fouling organisms and accumulated detritus were cleared from cages by brushing the sides and replacing the lids every $3 \mathrm{wk}$. In May, all plates were collected during 1 wk, during daytime high tides. Plates were placed individually into a seal-top plastic bag immediately after removal from the substratum. A narcotizing technique of $\mathrm{MgCl}_{2} \cdot 6 \mathrm{H}_{2} \mathrm{O}$ in solution isotonic to seawater (Steedman 1976, p. 92), was used to extract the mobile invertebrate fauna. Samples were rinsed out of the algal cover using filtered seawater, collected in a plankton mesh filter (mesh size $200 \mu \mathrm{m}$ ) and preserved in $10 \%$ seawater-formalin. Staining with Eosin aided detection of the invertebrates amongst the detritus (Eleftheriou \& Holme 1984). The invertebrate fauna in each sample was identified to the level of major taxonomic group (class, order) and their abundance determined. The specific surface area of each plate was determined using a 'BIOQUANT II' digitizing system ( $R$ \& M Biometrics Inc.) in conjunction with an Apple Ile personal computer, thus allowing standardization of abundances to densities in individuals per $100 \mathrm{~cm}^{2}$ (ind. $100 \mathrm{~cm}^{-2}$ ). All algae on the plates were carefully removed, using scalpel and forceps, and dried to constant weight at $80^{\circ} \mathrm{C}$, allowing estimation of algal biomass as dry weight. Algae were not scraped from the plates, in order to minimize the content of calcium carbonate derived from the experimental substratum.

In order to establish possible influences of the use of experimental substrata on densities of invertebrates, natural and experimental substrata were compared. At the beginning and again at the end of the experiment samples of natural substrata (2 replicates each), approximately equal in size to the experimental plates, were taken from 1 territorial and 1 non-territorial site per area, and the invertebrate fauna were sampled as above $(n=16)$.

In February, 5 specimens of Stegastes apicalis living in close proximity to each experimental area were collected, while in May each fish occupying an experimental territory was collected to examine the stomach contents ( $n=10$ for February, $n=6$ for May). A points method modified from Jones (1968) was used. The contents of each stomach was mixed with $10 \%$ sea- 
water-formalin and poured into a Petri dish. For each stomach sample 15 randomly-chosen subsamples were examined under a dissecting microscope with an ocular grid, on which 20 points were chosen randomly. The occurrence of 3 categories of material was determined for these 20 points in every subsample: 'algal fragments', 'invertebrate fragments' and 'empty or unidentifiable matter', thus allowing determination of percentage composition of identifiable stomach content.

Analysis. Estimates of algal dry weight and densities of invertebrates from the experiment were analysed using $F$-ratios and degrees of freedom derived according to Winer (1971). Cochran's test was used to test for heteroscedasticity and data was log-transformed when necessary to homogenize variances. Where relevant means were ranked using the Student-Newman-Keuls procedure (Underwood 1981). Correlations between densities and algal dry weight were examined. The stomach contents of Stegastes apicalis were analysed for differences between areas and between February and May, using 2-factor analyses of variance (both factors fixed and orthogonal). Prior to the analyses the data was transformed to arcsine to normalize the distribution (Winer 1971). Samples from natural substrata collected during May were compared with experimental plates using 3-factor analyses of variance with 'Area', 'Territoriality' and 'Substratum' (all factors fixed and orthogonal). In order to maintain equal sample sizes, 2 experimental samples (from uncaged treatments) were chosen randomly from the same sites used for the coliection of natural samples. Densities of invertebrates from natural substrata between February and May were compared in 3-factor analyses of variance with 'Area', 'Territoriality' and 'Month' as fixed and orthogonal factors.

\section{RESULTS}

\section{Experimental investigation}

The mobile invertebrate fauna on the experimental substrata was dominated by crustacean taxa. Harpacticoid copepods and gammarid amphipods were the most prominent groups, with overall mean densities of 97.5 and 66.2 ind. $100 \mathrm{~cm}^{-2}$, respectively (see Table 1).

Table 1. List of taxonomic groups and their mean densities per $100 \mathrm{~cm}^{2}( \pm \mathrm{SE})$ in decreasing order of abundance; $n=72$ plates

\begin{tabular}{|llr|}
\hline Crustacea & Others & Ind. $100 \mathrm{~cm}^{-2}$ \\
\hline Harpacticoida & & $97.6(8.5)$ \\
Gammaroidea & & $66.2(5.3)$ \\
Tanaidacea & Polychaeta & $58.7(3.9)$ \\
Isopoda & & $58.0(7.4)$ \\
Ostracoda & & $39.5(3.4)$ \\
& Gastropoda & $23.0(2.3)$ \\
Cumacea & & $17.8(5.3)$ \\
Caprellidea & & $14.2(5.9)$ \\
Calanoida & & $10.7(2.0)$ \\
& Platyhelminthes & $9.5(3.2)$ \\
& Pycnogonida & $1.3(1.1)$ \\
& Ophiuroidea & $1.2(0.5)$ \\
& & \\
\hline
\end{tabular}

Differences in the densities of these 2 groups were analysed separately from the analyses of total density.

Total density of invertebrates did not vary between the 2 areas, but did differ between individual sites (Table 2); this small-scale variability was due to differences between territorial sites under uncaged conditions (Table 3). Territorial habitats were found to

Table 2. Four-factor, mixed-model analyses of variance for the 3 density parameters and algal dry weight. Indicated are: degrees of freedom (df), mean squares, $F$-values and significance thereof; $n=72$. Data for Harpacticoida and total density were transformed to logarithms to stabilize the variances. In this and subsequent tables: NS, not significant $(p>0.05), \cdot 0.05>p>0.01$, $\cdots 0.01>p>0.001, \cdots p<0.001$

\begin{tabular}{|c|c|c|c|c|c|c|c|c|c|c|c|c|c|}
\hline \multirow[t]{2}{*}{ Source of variation } & \multirow[t]{2}{*}{$\mathrm{df}$} & \multicolumn{3}{|c|}{ Total density } & \multicolumn{3}{|c|}{ Harpacticoida } & \multicolumn{3}{|c|}{ Gammaroidea } & \multicolumn{3}{|c|}{ Algal dry weight } \\
\hline & & $\begin{array}{l}\text { Mean } \\
\text { square }\end{array}$ & $F$ & Sig. & $\begin{array}{l}\text { Mean } \\
\text { square }\end{array}$ & $F$ & Sig. & $\begin{array}{l}\text { Mean } \\
\text { square }\end{array}$ & $F$ & Sig. & $\begin{array}{l}\text { Mean } \\
\text { square }\end{array}$ & $F$ & Sig. \\
\hline \multicolumn{14}{|l|}{ Treatments: } \\
\hline Area & 1 & 0.092 & 2.788 & NS & 0.009 & 0.056 & NS & 2448.67 & 0.703 & NS & 0.018 & 0.304 & NS \\
\hline Caging & 1 & 1.344 & 25.358 & $\cdots$ & 3.403 & 24.659 & $\cdots$ & 28171.11 & 8.835 & $\cdot$ & 0.268 & 20.489 & $\cdots$ \\
\hline Territoriality & 1 & 0.685 & 20.758 & $\cdots$ & 1.581 & 10.006 & $\cdot$ & 7299.18 & 2.094 & NS & 0.725 & 12.066 & $\cdots$ \\
\hline Site (Area, Terr.) & 8 & 0.033 & 2.750 & $\cdot$ & 0.158 & 2.078 & NS & 3484.84 & 3.362 & $\cdots$ & 0.060 & 4.140 & $\cdots$ \\
\hline \multicolumn{14}{|l|}{ Interactions: } \\
\hline Area $\times$ Cagung & 1 & 0.067 & 1.264 & NS & 0.225 & 1.630 & NS & 3973.86 & 1.246 & NS & 0.002 & 0.171 & NS \\
\hline Area $\times$ Territoriality & 1 & 0.091 & 2.758 & NS & 0.164 & 1.037 & NS & 137.99 & 0.039 & NS & 0.091 & 1.522 & NS \\
\hline Caging $\times$ Temtoriality & 1 & 0.374 & 7.057 & $\cdot$ & 0.662 & 4.797 & NS & 1696.39 & 0.532 & NS & 0.279 & 21.329 & $\cdots$ \\
\hline Caging $\times$ Site (Area, Terr.) & 8 & 0.053 & 4.417 & $\cdots$ & 0.138 & 1.815 & NS & 3188.65 & 3.076 & $\cdots$ & 0.013 & 0.902 & NS \\
\hline Area $\times$ Caging $\times$ Territoriality & 1 & 0.082 & 1.547 & NS & 0.002 & 0.014 & NS & 942.40 & 0.295 & NS & 0.014 & 1.049 & NS \\
\hline Residual & 48 & 0.012 & & & 0.076 & & & 1036.53 & & & 0.014 & & \\
\hline
\end{tabular}


Table 3. Results of Student-Newman-Keuls (SNK) tests indicating only significant difference between individual sites. Numbers in main body of table indicate the identity of the sites in question; significant differences at the $5 \%$ level are represented by ' $>$ ' $T$ : territorial; NT: non-territorial; C: caged; U: uncaged

\begin{tabular}{|c|c|c|c|c|c|c|c|c|}
\hline & \multicolumn{4}{|c|}{ Area 1} & \multicolumn{4}{|c|}{ Area 2} \\
\hline & & & & & & & & \\
\hline & C & U & $\mathrm{C}$ & $\mathrm{U}$ & $\mathrm{C}$ & $\mathrm{U}$ & c & $\mathrm{U}$ \\
\hline Total density & & $1>2$ & & & & $7,9>8$ & & \\
\hline Gammaroidea & & $1>2,3$ & & & $7,9>8$ & & $12>11$ & \\
\hline Algal dry weight & & & & & & $7,9>8$ & & \\
\hline
\end{tabular}

support greater densities than did non-territorial habitats, with mean densities of 470.1 and 327.6 ind. $100 \mathrm{~cm}^{-2}$, respectively (Fig. 1). Caging resulted in an increase in total density, predominantly outside territories, as indicated by the Caging $\times$ Territoriality interaction (Table 2; Fig. 1), while in some cases a reduction in density was observed in territorial sites (Sites 1, 3 and 7; Fig. 1), as indicated by the Caging $x$ Site interaction (Table 2).

Caged substrata contained larger densities of harpacticoids than did uncaged substrata, and territories included larger densities than found in non-territorial habitats (Fig. 2). The analysis indicated no differences at either the large or small spatial scale (Table 2).

The analysis of gammarid density illustrated significant variability between sites (Table 2), under caged and uncaged conditions, inside and outside of

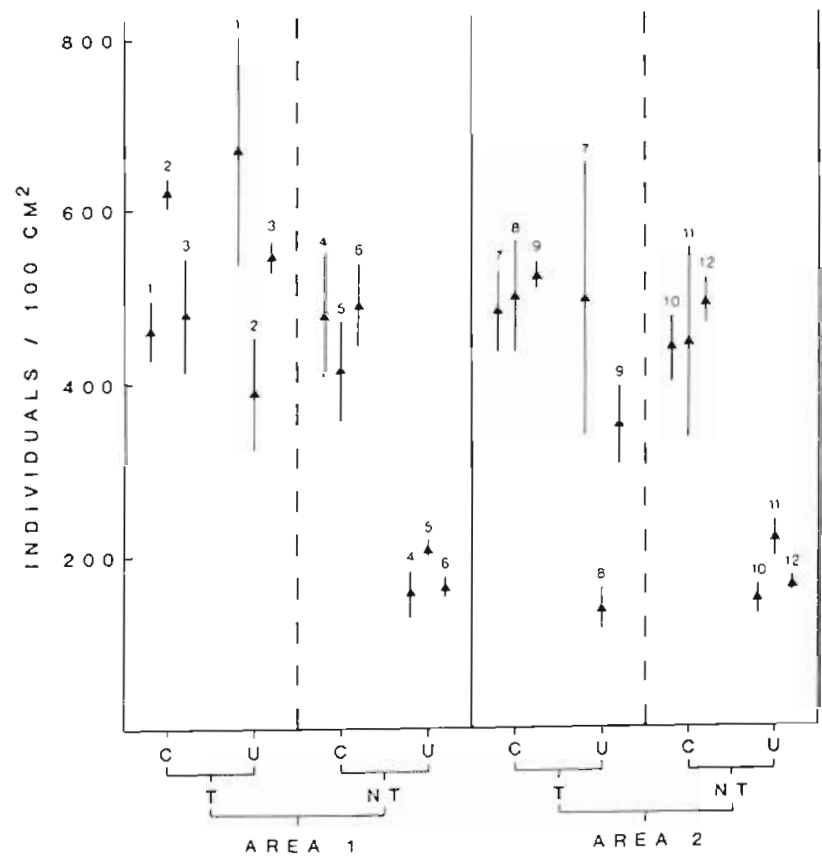

Fig. 1. Mean total density ( $\pm \mathrm{SE}$ ) of invertebrates per $100 \mathrm{~cm}^{2}$, separated by the 3 orthogonal factors 'Area', 'Territoriality' and 'Caging'. Numbers identify individual sites; $n=72$ replicates. T: territorial; NT. non-territorial; C: caged; U: uncaged

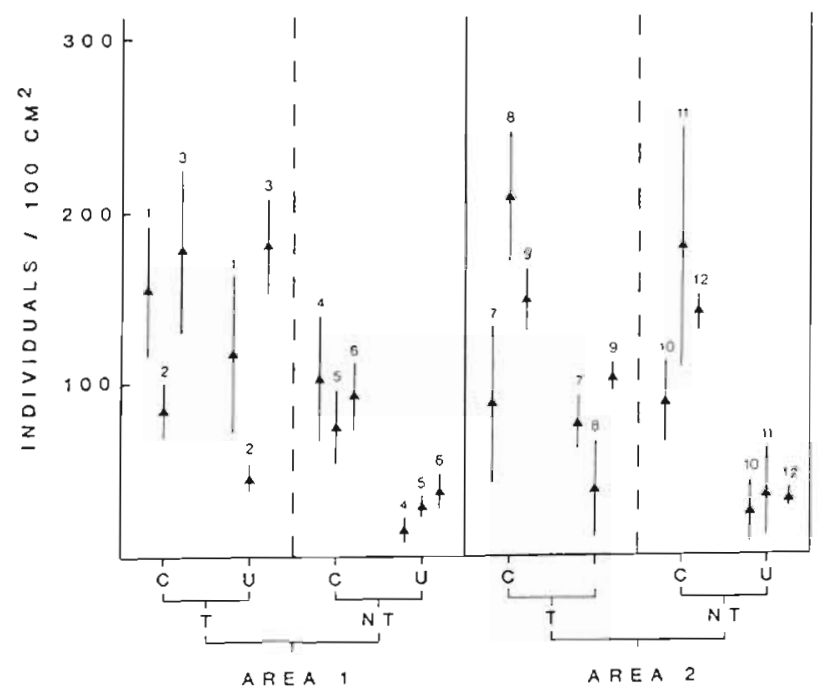

Fig. 2. Mean density ( \pm SE) of harpacticoid copepods per 100 $\mathrm{cm}^{2}$, separated by the 3 factors 'Area', 'Territoriality' and 'Caging'. Numbers identify individual sites; $n=72$ replicates.

T: territorial; NT: non-territorial; C: caged; U: uncaged

territories (Table 3). Thus, gammarids appeared very variable in their distribution (Fig. 3). Caging resulted in an increase in density in all but one case (Site 1 ; Fig. 3), but the extent of the change in density varied considerably between sites, as evidenced by the significant Caging $\times$ Site interaction (Table 2 ; Fig. 3 ) .

Algal dry weight showed variability on the small spatial scale, i.e between individual sites (Table 2; Fig. 4). This was the case particularly for Site 8 under uncaged conditions, as indicated by the SNK test (Table 3). Territories contained greater algal biomasses than did non-territorial habitats (Table 2; Fig. 4). The effect observed for caging was, however, different from the pattern found for the invertebrates. Caging resulted either in a decrease (inside territories), or in no change in algal dry weight (outside territories) (as indicated by the Caging $\times$ Territoriality interaction in Table 2). A change in the algal composition was apparent on caged plates. A dense, filamentous algal cover, visually similar to uncaged plates, developed inside the cages during the first 2 mo. At the end of the experiment, 


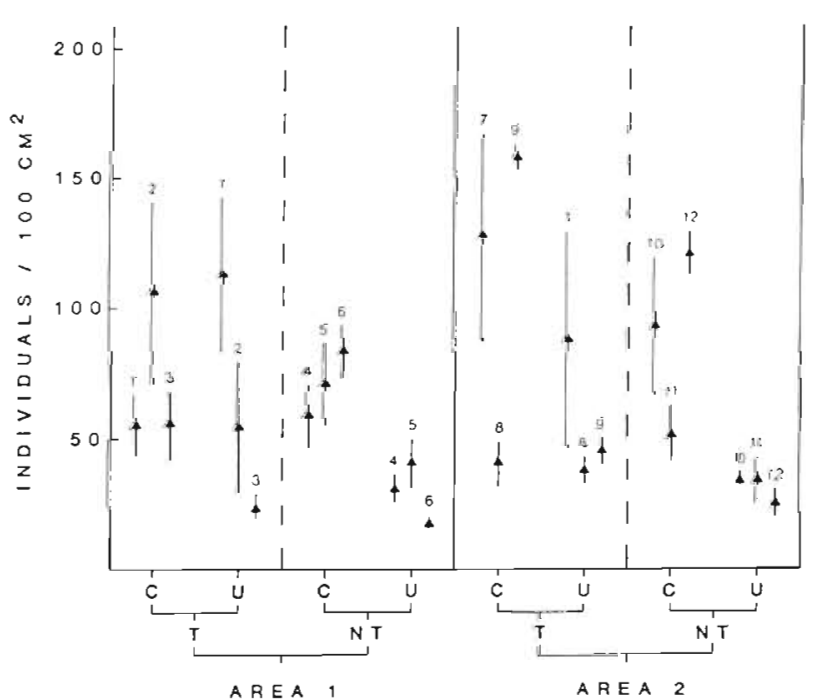

Fig. 3. Mean density ( \pm SE) of gammarid amphipods per 100 $\mathrm{cm}^{2}$, separated by the 3 orthogonal factors 'Area', 'Territoriality' and 'Caging' Numbers identify individual sites; $n=72$ replicates. $\mathrm{T}$ : territorial; NT: non-territorial; $\mathrm{C}$ : caged; $\mathrm{U}$ : uncaged

however, the plates were dominated by larger, more fleshy species such as Spyridia filamentosa, Jania spp. and Hypnea spp.

Correlation analyses between invertebrate densities and algal dry weight were limited to uncaged treatments, since the above analyses indicated a distinct discrepancy between these variates for caged treatmonts. Thus, factors other than algal biomass appeared to influence density of invertebrates in caged samples. Densities of all 3 taxal groups showed significant positive correlations with algal biomass under uncaged conditions (total density of invertebrates: $r=0.57$, $p<0.001$; Harpacticoida: $\quad r=0.51, \quad p<0.001$; Gammaroidea: $r=0.37,0.05>p>0.01$.

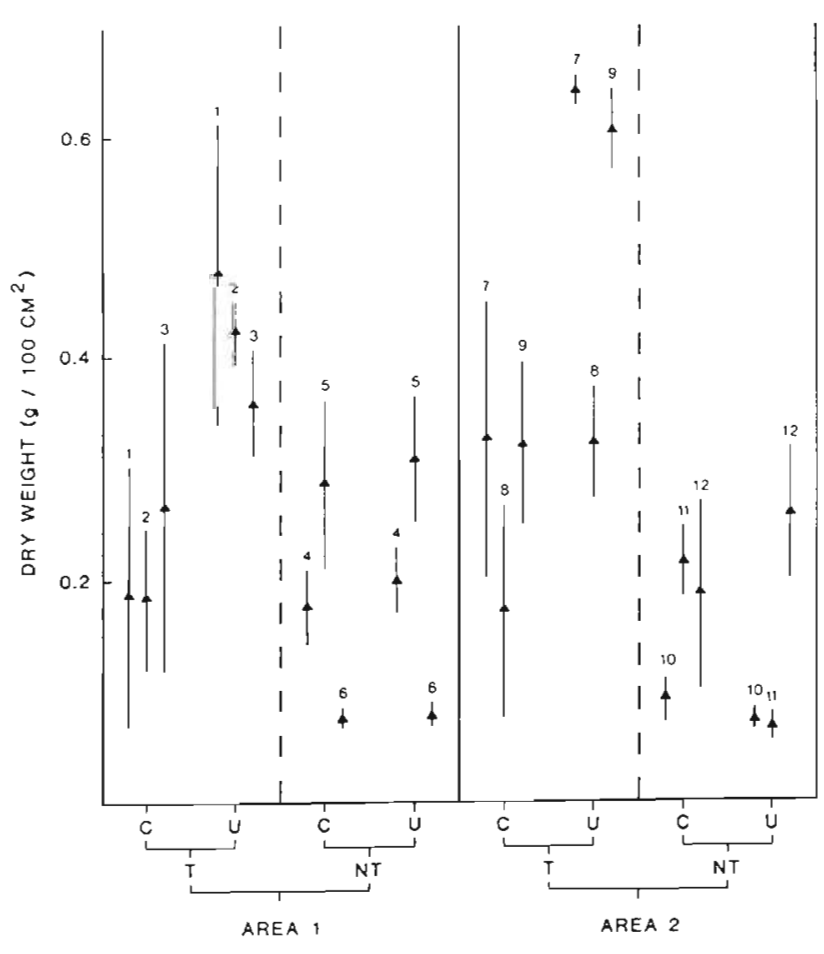

Fig. 4. Mean algal dry weight per $100 \mathrm{~cm}^{2}$ ( $\pm \mathrm{SE}$ ), separated by the 3 orthogonal factors 'Area', 'Territoriality' and 'Caging' Numbers identify individual sites; $n=72$ replicates. T: territorial; NT: non-territorial; C: caged; U: uncaged

\section{Naturaì sampies}

No differences in densities of harpacticoid, gammarid or total invertebrates were detected between natural and experimental substrata (Table 4). Similarly, there were no differences in densities on natural substrata between February and May (Table 5).

Table 4. Results of 3-factor analyses of variance testing for differences in densities of invertebrates between natural and uncaged experimental substrata. Indicated are; degrees of freedom (df), mean squares, $F$-values and significance thereof; $n=16$. Data for Gammaroidea and total density were transformed to logarithms to stabilize the variances

\begin{tabular}{|c|c|c|c|c|c|c|c|c|c|c|}
\hline \multirow[t]{2}{*}{ Source of variation } & \multirow[t]{2}{*}{$\mathrm{df}$} & \multicolumn{3}{|c|}{ Total density } & \multicolumn{3}{|c|}{ Harpacticoida } & \multicolumn{3}{|c|}{ Gammaroidea } \\
\hline & & Mean square & $F$ & Sig. & Mean square & $F$ & Sig. & Mean square & $F$ & Sig \\
\hline \multicolumn{11}{|l|}{ Treatments: } \\
\hline Area & 1 & 0.0272 & 1.346 & NS & 92.55 & 0.099 & NS & 0.000393 & 0.008 & NS \\
\hline Territoriality & 1 & 0.632 & 31.351 & $\cdots$ & 26266 & 28.228 & $\cdots$ & 0.577 & 11.069 & $\cdot$ \\
\hline Substrata & 1 & 0.0169 & 0.843 & NS & 1035.52 & 1.113 & NS & 0.000221 & 0.004 & NS \\
\hline \multicolumn{11}{|l|}{ Interactions: } \\
\hline Area $\times$ Territoriality & 1 & 0.00419 & 0.208 & NS & 41.70 & 0.045 & NS & 0.0272 & 0.522 & NS \\
\hline Area $\times$ Substrata & 1 & 0.0255 & 1.268 & NS & 4581.15 & 4.923 & NS & 0.0576 & 1.104 & NS \\
\hline Terr. $\times$ Substrata & 1 & 0.00351 & 0.174 & NS & 1670.78 & 1.795 & NS & 0.0533 & 1.021 & NS \\
\hline Area $\times$ Territoriality $\times$ Substrata & 1 & 0.000175 & 0.008 & NS & 1856.73 & 1.795 & NS & 0.0649 & 1.246 & NS \\
\hline Residual & 8 & 0.0202 & & & 930.51 & & & 0.0522 & & \\
\hline
\end{tabular}


Table 5. Three-factor analyses of variance of densities of invertebrates on natural substrata collected at the beginning and end of the experimental period. Indicated are: degrees of freedom (df), mean squares, $F$-values and significance thereof; $n=16$. Data for Gammaroidea were transformed to logarithms to stabilize the variances

\begin{tabular}{|c|c|c|c|c|c|c|c|c|c|c|}
\hline \multirow{2}{*}{ Source of variation } & \multirow[t]{2}{*}{ df } & \multicolumn{3}{|c|}{ Total density } & \multicolumn{3}{|c|}{ Harpacticoida } & \multicolumn{3}{|c|}{ Gammaroidea } \\
\hline & & Mean square & F & Sig. & Mean square & $F$ & Sig. & Mean square & $F$ & Sig. \\
\hline \multicolumn{11}{|l|}{ Treatments: } \\
\hline Area & 1 & 22666 & 2.009 & NS & 1789 & 1.642 & NS & 0.00453 & 0.053 & NS \\
\hline Territoriality & 1 & 440269 & 39.018 & $\cdots$ & 30800 & 28.270 & $\cdots$ & 2.124 & 24.577 & $\cdots$ \\
\hline Month & 1 & 12769 & 1.1 .32 & NS & 65 & 0.060 & NS & 0.00682 & 0.079 & NS \\
\hline \multicolumn{11}{|l|}{ Interactions: } \\
\hline Area $\times$ Territoriality & 1 & 8562 & 0.759 & NS & 1066 & 0.978 & NS & 0.0452 & 0.522 & NS \\
\hline Area $\times$ Month & 1 & 8986 & 0.796 & NS & 490 & 0.450 & NS & 0.0232 & 0.268 & NS \\
\hline Terr. $\times$ Month & 1 & 10502 & 0.931 & NS & 753 & 0.692 & NS & 0.00104 & 0.012 & NS \\
\hline Area $\times$ Territoriality $\times$ Month & 1 & 3412 & 0.302 & NS & 285 & 0.262 & NS & 0.0431 & 0.498 & NS \\
\hline Residual & 8 & 11280 & & & 1089 & & & 0.0864 & & \\
\hline
\end{tabular}

\section{Stomach contents}

Filamentous algae clearly dominated the identifiable contents in terms of percentage occurrence, with algal fragments comprising on average $83.82 \% \quad$ (SE $=$ $4.41 \%$ ) and the rest being invertebrates. No difference was detected between areas or between February and May in the abundance of either algal or invertebrate fragments (Table 6).

\section{DISCUSSION}

Territories of Stegastes apicalis contained larger densities of mobile invertebrates than found in nonterritorial habitats. Caging led to an increase in densities of harpacticoids, gammarids and the total assemblage of invertebrates. While densities outside territories showed relatively little variation between areas and between sites, territorial habitats displayed a larger variability in densities between individual sites, often resulting in significant interactions between the factors 'Territoriality', 'Caging' and 'Site'.

\section{Effect of territoriality}

In the following discussion emphasis is placed on the effect of territoriality. Nevertheless, one should remember that it is entirely possible that differences between territorial and non-territorial treatments could also be the result of differences in the places where damselfishes like to place their territories, such as in areas where plants are more productive. It does not seem possible to design an experiment that removes this problem.

It has been stated frequently in the literature that differences in abundance of small, mobile invertebrates depend upon the size (Edgar 1983, Gunnill 1983), as well as the availability of algae per unit area (e.g. Lobel 1980). Thus, one would expect the greater densities of invertebrates on territorial than on non-

Table 6. Results of the 2 -factor analyses of variance testing for differences in stomach contents (algal and invertebrate fragments) between the 2 areas and between February and May. Indicated are: degrees of freedom (df), mean squares, F-values and significance thereof; $n=16$. Data was transformed to arcsine to normalize the distributions

\begin{tabular}{|c|c|c|c|c|c|c|c|}
\hline \multirow[t]{2}{*}{ Source of variation } & \multirow[t]{2}{*}{$\mathrm{df}$} & \multicolumn{3}{|c|}{ Algae } & \multicolumn{3}{|c|}{ Invertebrates } \\
\hline & & Mean square & $F$ & Sig. & Mean square & $F$ & Sig \\
\hline \multicolumn{8}{|l|}{ Treatments: } \\
\hline Area & 1 & 0.00007 & 0.015 & NS & 0.0053 & 1.709 & NS \\
\hline Months & 1 & 0.01902 & 4.226 & NS & 0.0001 & 0.032 & NS \\
\hline \multicolumn{8}{|l|}{ Interaction: } \\
\hline Area $\times$ Months & 1 & 0.0101 & 2.244 & NS & 0.0002 & 0.065 & NS \\
\hline Residual & 12 & 0.0045 & & & 0.0031 & & \\
\hline
\end{tabular}


territorial plates to be paralleled by a change in algal dry weight. This was the case for uncaged samples, with greater algal biomass inside territories than outside. The analyses of uncaged samples indicated that densities showed significant, positive correlations with algal biomass. The low correlation coefficients obtained suggest 2 things. First, there was a great variability in densities on the 'Site' scale, especially for territorial habitats. Such highly variable densities have been reported also by Lobel (1980) for mobile invertebrates inside territories. Second, factors other than algal biomass are important in influencing the abundance of the invertebrates inside territories. Coull \& Wells (1983) examined the phytal meiofauna on a temperate rocky shore and found that structural complexity of algae (i.e. surface to volume ratios) rather than biomass gave the best correlations with faunal abundances. Thus, structural complexity of habitats may significantly influence population density. No quantitative measure of complexity of the algal cover was collected in the present study, and thus this hypothesis could not be tested. Nevertheless, from the distinct differences in dry weight of algal turf observed between territorial and non-territorial treatments, one would predict that cover of algae inside territories should be of greater structural complexity than cover outside territories. Thus, the greater biomass and perhaps greater structural complexity of algal cover inside territories appeared to provide a refuge for the invertebrate fauna. The algal mats might provide increased availability of food, either in terms of filamentous algae, or increased amount of particulate organic matter and detritus that is deposited in these mats (Hicks 1980). Complex environments may also permit a moderation of or protection from predation by the provision of spatial refuges (Coull \& Wells 1983). Territorial pomacentrids aggressively exclude other herbivorous fishes such as scarids, acanthurids and siganids (Lassuy 1980, Hixon 1985), while a number of small predators are consistently ignored (Itzkowitz 1974). Thus, mortality of invertebrates due to the activities of large grazers (as reported by Brock 1979), could be reduced inside territories because of the behavioural patterns of Stegastes apicalis.

The analysis of stomach contents of Stegastes apicalis indicated a predominance of filamentous algal fragments. This agreed with findings by Lassuy (1980), Lobel (1980) and Robertson \& Polunin (1981) for other Stegastes species. In the present study, invertebrates made up only a small component $(16.18 \%)$ of the overall diet, which is comparable to the $14 \%$ by volume recorded for $S$. planifrons (Lobel 1980). Other herbivorous pomacentrids have also been found to contain invertebrates in their stomachs (e. g. Hobson 1974). This could indicate that invertebrates are either taken incidentally or as a dietary supplement. It has been suggested that such animal matter, despite low occurrence, forms an important dietary component, to satisfy the need for nitrogen, which is rare in plants (Lobel 1980).

Feeding by the moon wrasse Thalassoma lunare and other predatory, benthic feeding fishes was observed inside territories of Stegastes apicalis throughout the study, and such feeding did not elicit any aggressive response from the pomacentrid. The access permitted to many predatory fishes could result in considerable predation on the invertebrate fauna inside territories. The increased algal cover inside territories may, however, provide increased refuge from the visual predation by these fishes. In areas unaffected by territorial pomacentrids the cover of algae was considerably reduced by grazing (Miller 1982).

\section{Effect of caging}

Caging resulted in an increase in faunal densities, and algal biomass changed in composition and either underwent a reduction (inside territories) or no change in biomass (outside territories). A shift in species composition inside cages, favouring a few prominent macroalgae, has been reported previously (e.g. Lassuy 1980). Caging experiments are known to be affected by various confounding effects which have been addressed repeatedly (e.g. Choat \& Kingett 1982, Kenneliy 1983). Russ (1987) and Scott \& Russ (1987) used similar types and sizes of cages and plates to test for possible caging effects using the method proposed by Kennelly (1983), and reported no significant artefactual effects on algal biomass over a 1 mo period.

Alternatively, the exclusion of large grazers and predators may have led to an increase in the densities of small, herbivorous invertebrates. Intense grazing pressure by micrograzers (sensu Vadas 1986) could thus have produced the observed reduction in algal biomass to levels equal to or below uncaged treatments. Similar results were obtained by Brawley \& Adey (1981) and Kennelly (1983). Brawley \& Adey reported increases in densities and feeding intensity of micrograzers upon exclusion of fishes from their experimental reef system, resulting in drastic changes in algal cover, with preference to algal species that were consumed rarely or not at all by the invertebrates. The caged plates in the present experiment were dominated by Spyridia filamentosa, Jania spp. (which is lightly calcified) and Hypnea spp. Considering the evidence put forward by Brawley \& Adey, it seems quite likely that none of these algae were fed upon preferentially by micrograzers, but their abundance might be the direct result of the high densities of micrograzers. 
Detailed knowledge of feeding requirements and consumption rates of small, tropical invertebrates is lacking. Nevertheless, the effect of micrograzers on the algal cover, in addition to the effect of predation on the invertebrates, would have to be taken into account in future caging experiments longer than 1 mo in duration. The selective territorial defence by pomacentrids, allowing access of small predatory fishes, might therefore have the indirect effect of maintaining the mobile invertebrate fauna at a level low enough to avoid those changes that were observed under caged conditions inside territories. Invertebrate densities in uncaged conditions might, however, be high enough to explain partially the contradictory findings of fast rates of algal removal inside territories despite apparently smaller bite rates of grazing fishes (Russ 1987).

\section{CONCLUSIONS}

The major findings of this study are:

(1) Densities of small invertebrates were significantly greater in algal turfs inside territories than outside territories of Stegastes apicalis. Increased availability of food and/or refuges from predators due to increased structural heterogeneity of the environment are possible explanations for this.

(2) An increase in densities of invertebrates, accompanied by a change in algal composition and reduction in algal biomass were observed in caged treatments. The reduction in algal biomass may have been caused by temporally delayed cage effects and/or by increased intensity of grazing by the herbivorous species in the invertebrate community.

Acknowledgements. I sincerely thank Drs J. H. Choat and G. R. Russ for their helpful comments on experimentation and their criticism of the manuscript. I also thank Dr A. J. Underwood for his advice on design and analyses. My special thanks to $L$. Axe for help with the field work. Finally, I thank 3 anonymous referees for helpful criticisms of the manuscript.

\section{LITERATURE CITED}

Allen, G. R. (1975). Damselfishes of the South Seas. T F. H. Publications Inc, Brookvale

Brawley, S. H., Adey, W H. (1977). Territorial behavior of threespot damselfish (Eupomacentrus planifrons) increases reef algal biomass and productivity. Environ. Biol. Fish. 2: $45-51$

Brawley, S. H., Adey, W. H. (1981). The effect of micrograzers on algal community structure in a coral reef microcosm. Mar. Biol. 61. 167-77

Brock, R. E. (1979). An experimental study on the effects of grazing by parrotfishes and role of refuges in benthic community structure. Mar. Biol. 51. 381-388
Carpenter, R. C. (1986). Partitioning herbivory and its effects on coral reef algal communities. Ecol. Monogr. 56 (4): 345-363

Choat, J. H., Kingett, P. D. (1982). The influence of fish predation on the abundance cycle of an algal turf invertebrate fauna. Oecologia (Berl.) 54: 88-95

Coull, B. C., Wells, J. B. J. (1983). Refuges from fish predation: experiments with phytal meiofauna from the New Zealand rocky intertidal. Ecology 64 (6): 1599-1609

Day, R. W. (1977). Two contrasting effects of predation on species richness in coral reef habitats. Mar. Biol. 44: 1-5

Edgar, G. J. (1983). The ecology of south-east Tasmanian phytal animal communities. I. Spatial organization on a local scale. J. exp. mar. Biol. Ecol. 70: 129-157

Eleftheriou, A., Holme, N. A. (1984). Macrofauna techniques. In: Holme, N. A., McIntyre, A. D. (eds.) Methods for the study of marine benthos, 2nd edn. Blackwell, Oxford, p. $140-216$

Gunnill, F. C. (1983) Seasonal variations in the invertebrate faunas of Pelvetia fastigiata (Fucaceae): effects of plant size and distribution. Mar. Biol. 73: 115-130

Harmelin-Vivien, M. L. (1981). Trophic relationships of reef fishes in Tulear (Madagascar), Oceanologica Acta 3: $365-74$

Hatcher, B. G. (1983). Grazing in coral reef ecosystems. In: Barnes D. J. (ed.) Perspectives on coral reefs. Australian Institute of Marine Science, Townsville, p. 164-179

Hatcher, B. G., Larkum, A. W. D. (1983). An experimental analysis of factors controlling the standing crop of the epilithic algal community on a coral reef. J. exp. mar. Biol. Ecol. 69: 61-84

Hay, M. E. (1985). Spatial patterns of herbivore impact and their importance in maintaining algal species richness. Proc, 5th Int. Coral Reef Symp., Tahiti, Vol. 4: 29-34

Hicks, G. R. F. (1980). Structure of phytal harpacticoid copepod assemblages and the influence of habitat complexity and turbidity. J. exp. mar. Biol. Ecol. 44: 157-92

Hixon, M. A. (1985). Fish grazing and community structure of reef coral and algae: a synthesis of recent studies. In: Reaka M. L. (ed.) The ecology of coral reefs. NOAA Symp. Ser. Undersea Res., Vol. 3. NOAA Undersea Research Program, Rodeville, p. 9-15

Hobson, E. S. (1974). Feeding relationships of teleostean fishes on coral reefs in Kona, Hawaii. Fish. Bull. U. S. 72 (4): $915-1031$

Itzkowitz, M. (1974). A behavioural reconnaissance of some Jamaican reef fishes. Zool. J. Linn. Soc. 55: 87-118

Jones, R. S. (1968). A suggested method for quantifying gut contents in herbivorous fishes. Micronesica 4 (2): 369-371

Kennelly, S. J. (1983). An experimental approach to the study of factors affecting algal colonization in a sublittoral kelp forest. J. exp. mar. Biol. Ecol. 68: 257-276

Lassuy, D. R. (1980). Effects of 'farming' behaviour by Eupomacentrus lividus and Hemiglyphidodon plagiometopon on algal community structure. Bull. mar. Sci. 30: 304-312

Lewis, S. M. (1986). The role of herbivorous fishes in the organization of a Caribbean reef community. Ecol. Monogr. 56 (3): 183-200

Lobel, P. S. (1980). Herbivory by damselfishes and their role in coral reef community ecology. Bull. mar. Sci. 30: 273-89

Miller, A. C. (1982). Effects of differential fish grazing on the community structure of an intertidal reef flat at Enewetak Atoll, Marshall Islands. Pacif. Sci. 36 (4): $467-482$

Ogden, J. C., Lobel, P. S. (1978). The role of herbivorous fishes and urchins in coral reef communities. Environ. Biol. Fish. 3: $49-63$ 
Robertson, D. R., Polunin, N. V. C. (1981). Coexistence: symbiotic sharing of feeding territories and algal food by some coral reef fishes from the Western Indian Ocean. Mar. Biol. 62: 185-195

Russ, G. R. (1987). Is rate of removal of algae by grazers reduced inside territories of tropical damselfishes? $\mathrm{J}$. exp. mar. Biol. Ecol. 110: 1-17

Sale, P. F. (1980). The ecology of fishes on coral reefs. Oceanogr. mar. Biol. A. Rev. 18: 367-421

Scott, F. J., Russ, G. R. (1987). Effects of grazing on species composition of the epilithic algal community on coral reefs of the central Great Barrier Reef. Mar Ecol. Prog. Ser. 39: 293-304
Steedman, H. F. (ed.) (1976). Zooplankton fixation and preservation. Monographs on oceanographic methodology. UNESCO Press, Paris

Underwood, A. J. (1981). Techniques of analysis of variance in experimental marine biology and ecology. Oceanogr. mar. Biol. A. Rev. 19: 513-605

Vadas, R. L. (1986). Herbivory. In: Littler, M. (ed.) Handbook. of phycological methods: methods for studying the ecology of macroalgae. Cambridge University Press, London, p. $531-571$

Winer, B. J. (1971). Statistical principles in experimental design, 2nd edn. McGraw-Hill Book Company, New York

This article was presented by Dr A. J. Underwood; it was accepted for printing on February 10, 1988 